\title{
Current Trends in Transportation Engineering
}

\author{
Ji Zhang ${ }^{1}$, Harshingar Patel ${ }^{2}$ and Zongzhi Li³ \\ ${ }^{1}$ Department of Civil, Architectural and Environmental Engineering, Illinois Institute of Technology, Chicago, IL 60616, USA \\ ${ }^{2}$ Department of HSE and Civil Engineering, The University of Petroleum and Energy Studies, Dehradun, Uttarakhand 248007, India \\ ${ }^{3}$ Department of Civil, Architectural and Environmental Engineering, Illinois Institute of Technology, Chicago, IL 60616, USA
}

*Corresponding author: Zongzhi Li, Professor, Department of Civil, Architectural and Environmental Engineering, Illinois Institute of Technology, Chicago, IL 60616, USA.

Received Date: October 28, 2019

Published Date: November 05, 2019

\section{Short Communication}

The ever-growing population, coupled with economic growth, has created high travel demand in every country. Various transportation facilities such as roads, bridges, traffic control and safety hardware, and multimodal installations are deployed over time to meet the required demand. However, expanding capacity of the existing transportation network to meet the system deficit inevitably needs extensive expenditures. The prohibitively high costs of preserving the existing transportation facilities further exacerbate pressure for transportation investment that goes beyond affordability of any country's economy. This creates an economic imbalance with ever compounding system deficit. Every economy in the current times is struggling with bridging the deficit of the transportation system supply in conjunction with well-preserved physical facilities while maximizing benefits to transportation users and non-users in terms of travel cost decreases, travel time savings, vehicle crash reductions, and air emission cutbacks, as well as enhanced system resilience and emergency preparedness caused by clime changes, natural disasters, and manmade extreme events. The goals within a broader context are not only to ensure efficient and safe movements of people and goods, but also to promote economic prosperity of the region in a sustainable way. Sustainability can be addressed by minimizing resource utilization, as well as maximizing useful service life cycles of various types of physical facilities. One of the major concerns for transportation decision-makers and managers to achieve these goals is damages to physical facilities caused by varying axle loads of different classes of heavy vehicles using the transportation system, coupled with non-load factors related to design standards, material types, construction quality, preservation history, weather conditions, and climatic features [1,2]. Over the last several decades, many innovative financing and budget allocation methods have been developed and adopted by transportation decision-makers and managers to attribute fair pricing to individual users of the system to mitigate the system deficit. For instance, Pigou worked on the theory of taxing industries in 1920 whose indirect costs causing adverse impacts on the society, and which are not covered in the private cost on the industries causing negative externalities accounted in the social costs, not covered in the private cost of the activity [3]. This theory was expanded by Buchanan et al. and used for freight transportation in 1949 by RAND corporation, and for transit system in New York in 1952 [4-6]. This theory was further employed by other researchers during the 1960s to determine user fees for transportation system provision [7-9]. The framework of transportation system pricing developed by Small et al. in 1989 was refined and applied in cities of Australia, Germany, China, Italy, India, Sweden, and United Arab Emirates. The strategy of transportation system pricing has also been implemented in the United States as a means of recovering transportation facility damages and mitigating traffic congestion [10-12]. The pricing is the marginal social cost attributable to individual users, which has been observed to increase the horizontal equity, decrease the cross-subsidies amongst users, and potentially reduce the system deficit [12-16]. Though public acceptance to transportation system pricing has always been a major factor deciding on its success, and at times causing discontinuation as in the case of Hong Kong [17-20]. Addressing social equity and ensuring efficiency and effectiveness of revenue utilization in alignment with maintaining the travel quality will increase public acceptance [21-30].

The recent technological advancements and inter-disciplinary impacts have initiated developments of smart cities, advanced technology/driverless vehicles, shared mobility service. Notable information technology (IT) developments in the context of sensing, telecommunication, high-performance computing, virtual reality/visualization in support of real-time data collection, 
processing, analysis and prediction, decision-making, and information dissemination have gradually led to radical changes in the transportation arena from reactive, disintegrated management of various transportation system components including travel demand, system supply, and vehicles accommodating people and goods to proactive, holistic management of all system components to achieve the highest level of overall system performance. This directly creates needs for new methodologies and technologies to identify strategies and measures for managing travel demand, expanding multimodal transportation capacity, and dynamically balancing travel demand and transportation supply for efficient system utilization. The need if it ever was, is more pronounced with the changing times, to provide efficient, effective, equitable transportation infrastructure with an optimal level of user service. The system deficit has to be bridged and charging a fair and equitable marginal cost attributable to each user is the need of the hour [2]. The essence is to assess impacts of travel demand on performance of physical facility conditions and user service, establish a fair and equitable pricing scheme, and conduct efficient and effective budget allocation to achieve sustainable transportation development and management in the long run.

\section{Acknowledgement}

The authors thank for support of research publication by the National Natural Science Foundation of China (No. 71871029) and Fundamental Research Funds for the Central Universities of China, CHD (No. 300102219306, No. 300102218404).

\section{Conflict of Interest}

No conflict of interest.

\section{References}

1. Li Z (2018) Transportation Asset Management: Methodology and Applications. CRC Press, Boca Raton, Florida, USA.

2. Patel H (2015) Methodology for performance-based transportation systems management simultaneously considering demand and supply, with pricing consideration. Available from Dissertations \& Theses @ Illinois Institute of Technology (1712620862), Chicago, Illinois, USA.

3. Pigou AC (1920) The Economies of Welfare. McMillan, London, UK.

4. Buchanan JM (1951) Knut Wicksell on marginal cost pricing. Southern Economic Journal, pp.173-178.

5. Walters AA (1954) Track costs and motor taxation. The Journal of Industrial Economics 2(2): 135-146.

6. Vickrey WS (1952) The revision of the rapid transit fare structure of the City of New York. Report 8. New York, USA.

7. Roth GJ, Thomson JM (1963) Road pricing, a cure for congestion? Report 204. Department of Applied Economics, University of Cambridge, Cambridge, UK.

8. Walters AA, Walters AA (1968) The economics of road user charges. Report 5. International Bank for Reconstruction and Development, Washington DC, USA.

9. Smeed RJ (1964) Road pricing: The economic and technical possibilities. The Smeed Report. Ministry of Transport, London, UK.

10. Small KA, Winston C, Evans CA (2012) Road Work: A New Highway Pricing and Investment Policy. Brookings Institution Press, Washington DC, USA.
11. Arnold R, Smith VC, Doan JQ Barry RN, Blakesley JL, et al. (2010) Reducing congestion and funding transportation using road pricing in Europe and Singapore. Report No. FHWA-PL-10-030. Federal Highway Administration, U.S. Department of Transportation, Washington DC, USA.

12. Ramjerdi F (1996) Road pricing and toll financing with examples from Oslo and Stockholm. Institute of Transport Economics, Oslo, Norway.

13. Maddison D (1996) Blueprint 5: The true costs of road transport. Earthscan, London, UK.

14. Button K, Verhoef E (1998) Road Pricing, Traffic Congestion and The Environment. Edward Elgar Publishing, Cheltenham, UK.

15. Ison S (2017) Road User Charging: Issues and Policies. Routledge, Abingdon, UK.

16. FHWA (1998) 1997 Federal highway cost allocation study final report. Federal Highway Administration, U.S. Department of Transportation, Washington DC, USA.

17. Litman T (2012a) London congestion pricing: implications for other cities. Victoria Transport Policy Institute, Victoria, British Columbia, Canada.

18. Litman T (2017a) Socially optimal transport prices and markets. Victoria Transport Policy Institute, Victoria, British Columbia, Canada.

19. Litman T (2012b) Pricing for traffic safety: how efficient transport pricing can reduce roadway crash risks. Transportation Research Record 2318(1): 16-22.

20. Litman T (2017b) Generated traffic and induced travel. Victoria Transport Policy Institute, Victoria, British Columbia, Canada.

21. Giuliano G (1994) Equity and fairness considerations of congestion pricing. Special Report 242. Transportation Research Board. The National Academies Press, Washington DC, USA.

22. Rajé F (2003) Impacts of road user charging/workplace parking levy on social inclusion/exclusion: gender, ethnicity and lifecycle issues-interim report: travel diaries. TSU REF 937. Transport Study Unit, The University of Oxford, Oxford, UK.

23. Parry I (2009) Pricing urban congestion. Annual Review of Resource Economics 1(1): 461-484.

24. Burris M, Lee S, Geiselbrecht T, Baker T (2013) Equity evaluation of sustainable mileage-based user fee scenarios. Report No. SWUTC/14/600451-00007-1. Southwest Region University Transportation Center, College Station, Texas, USA.

25. Kain J (1994) Impacts of congestion pricing on transit and carpool demand and supply. Special Report 242. Transportation Research Board. The National Academies Press, Washington DC, USA.

26. King D, Manville M, Shoup D (2007) The political calculus of congestion pricing. Transport Policy 14(2): 111-123.

27. Levine J, Garb Y (2000) Evaluating the promise and hazards of congestion pricing proposals: An access centered approach. Floersheimer Institute for Policy Studies, The Hebrew University, Mount Scopus, Jerusalem, Israel.

28. Vassallo JM, Sanchez-Solino A (2007) Subordinated public participation loans for financing toll highway concessions in Spain. Transportation Research Record 1996(1): 1-8.

29. Bain R (2009) Big numbers win prizes: twenty-one ways to inflate toll road traffic and revenue forecasts. Project Finance International, Leeds, UK.

30. Samuel P, Poole R (2000) Putting customers in the driver's seat: the case for tolls. Policy Study Report 274. Reason Public Policy Institute, Reason Foundation, Washington DC, USA. 